\title{
Online English Learning during Covid-19 Pandemic
}

\section{Dewi Sartipa}

Pendidikan Bahasa Inggris, Universitas Muhammadiyah Kotabumi, Lampung Utara

dewisartipa51@gmail.com

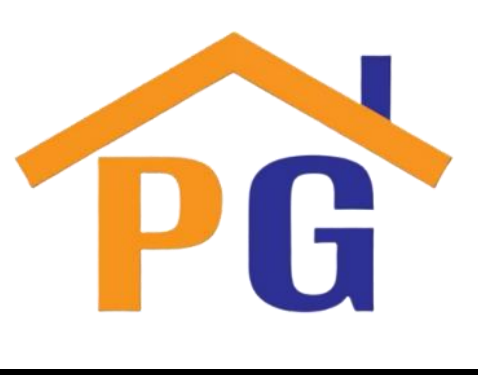

\section{Riwayat Artikel}

Diterima pada 20 Mei 2021

Revisi 1 pada 14 Juni 2021

Revisi 2 pada 20 Juni 2021

Disetujui pada 22 Juni 2021

\begin{abstract}
Purpose: This article aims to describe English learning in the Covid-19 Pandemic Era. This article also explains the importance of the Internet in the learning process and the importance of parents in the development of students in the Covid-19 Pandemic Era.

Research methodology: This study used a descriptive method.

Results: This study suggests that parents should motivate their children in this situation because the learning process is carried out at home, and only parents can directly monitor the learning process.

Limitations: This study has limitations. It is the information of parents who guide their students in the learning process, especially English Subject in the Covid-19 pandemic.

Contribution: The study is beneficial for teachers and parents to conduct a better learning strategy during Covid -19 pandemic.

Keywords: English, Pandemic, Online Learning

How to Cite: Sartipa, D. (2021). Online English Learning during Covid-19 Pandemic. Jurnal Humaniora dan Ilmu Pendidikan, $1(1), 64-69$.
\end{abstract}

\section{Introduction}

English is a global language that serves as the primary medium of international communication. English is widely taught in a variety of countries worldwide. According to Richards \& Rodger (1986, p.64-65), many residents in various countries use English to communicate at various important international meetings. Mastering English is essential because almost all global sources of information in various aspects of life use English. According to Crystal (2000, p.1), English is a global language. This statement represents the meaning that various nations use English to communicate with nations around the world. So, English is one of the international languages as well as a global language. Learning and understanding English is an unavoidable need. By studying English, a person will open their horizons and knowledge internationally.

English teaching is the key to the success of world interaction. The success of mastering this language simplifies the flow of togetherness between nations. This situation certainly encourages English teachers to be more creative and innovative in providing English language materials and learning media suitable and easily accessible to students. There are many digital media choices, such as google meet, google classroom, Whatsapp, and Zoom meetings, which teachers can choose. However, the effectiveness of learning is not only determined by the medium but rather by digital literacy. Digital literacy is the interest, attitude, and ability of individuals to use digital technology and communication tools to access, manage, integrate, analyze, evaluate information, build new knowledge and communicate with others effectively. The Coronavirus pandemic or Covid-19 disaster that is currently happening impacts various sectors, both the business world and the education sector. The obligation to social distancing, wear masks, wash hands and avoid crowds encourages the teaching and learning process (PBM) in schools and colleges to start shifting from face-to-face (offline) and online learning. This, of course, resulted in the school management, teachers, students, and parents being forced to be able to adjust to these conditions. They are starting to realize the importance of digital literacy so that the learning process continues even though it is still challenging, both for schools, students and parents. 


\section{Research Methodology}

This study uses a descriptive method and several teaching cases in the learning process in the pandemic.

\section{Online English Learning during Pandemic Covid-19}

Teachers have limitations in explaining learning material related to variations in learning methods that are carried out. In the previous conventional class, the teacher had creativity, flexibility, and diversity in the use of teaching methods that were adapted to the material, according to the rules, situations and learning environment, and so on. However, teachers experience limited ability in explaining because learning is done online. This also provides challenges to teachers and students in carrying out learning activities. Activities are limited to sharing learning materials, videos, assignments, voice messages, and information that have limited interaction patterns from teacher to student and student to teacher.

The interaction pattern between students is quite limited. Group or pair work activities have not been seen in learning, so activities that require students to discuss and in groups are still limited. Studentcentered learning cannot be done because all materials, activities, questions, assignments, and information are centered or sourced from the teacher. Teachers and students are also constrained by learning time which makes exposure, explanation, reinforcement, enrichment of learning materials, and material clarification difficult. For example, some students who do not understand a material during the specified learning period must ask the teacher directly through the teacher's personal WA. Teachers also have limited time and methods or techniques in giving explanations to students satisfactorily because it is pretty challenging to give them courageously. The same thing happened to students. Giving feedback, reinforcements, rewards, and sanctions to students is also very limited. Teachers usually provide corrections to collected student assignments or projects, provide verbal reinforcement and rewards such as the words "good, smart, uplifting," and/or provide similar symbols or emoticons to motivate students to learn and activate. However, giving sanctions to students who do not, have not, or are late in arranging assignments cannot be automatically given. The teacher only reminded them continuously every week so that they immediately set the assignment.

COVID-19 has had an impact on education in Indonesia. In the first four months of the COVID-19 pandemic emergency, education at all levels was carried out online. However, in this new normal period, several schools carried out face-to-face learning even though only three days a week and still paid attention to health protocols. The process of switching from online to face-to-face seems to make students feel less enthusiastic about taking face-to-face learning because they already feel comfortable with learning online. In the online system, they can learn while playing outside the house without getting a warning from the teacher, but learning cannot be left behind and the children get direct supervision from the teacher in this face-to-face system. During a pandemic, children continue to learn by observing health protocols. The reality in the field shows that there are still children who do not go to school even though they already know that learning is carried out face-to-face at school. In addition, this transition process makes children unprepared if they receive much material. This has an impact on children who seem not to pay attention to lessons. In this case, the teacher must be able to establish closeness with students to find out their characteristics. By knowing the characteristics of children, teachers can design appropriate learning methods. Adaptation and innovation of learning must be carried out by teachers (Puspitasari, Rahayu \& Rohmatunnazilah, 2020). Teachers must adapt again to children by adjusting their psychology. However, teachers must also innovate so that children are interested in taking part in learning. One form of teacher innovation is to develop creative learning methods so that children's interest in learning will revive.

In the 2013 curriculum, English as a foreign language is included in local content subjects where there is only one meeting in one week. With this short time, the teacher should be able to maximize the learning process to the maximum so that the learning objectives are achieved. English subjects for elementary school level aim to develop competency in communicating orally in daily school actions. However, in reality, learning English for elementary schools only emphasizes memorizing vocabulary. English teachers still use traditional methods in teaching English (Sartika, 2017). Young 
learners or young learners with ages ranging from 7-9 years (Pinter, 2011). Young learners have unique characteristics. Some of these characteristics are (Harmer, J 2007):

- Young learners learn either directly or indirectly from the surrounding environment.

- Their understanding is more profound if they see, hear, touch rather than just explaining material alone-Abstract learning is not suitable for them to prefer lessons that talk about themselves as the main topic and respond to them.

- They like to find things, make or draw things, imagine, move from one place to another, and solve puzzles.

- They get bored easily

- They are Enthusiastic about learning English

- Their attention to lessons is very short.

In an effort to understand their characteristics and maximize the learning process, teachers must be able to create creative learning models. The learning model includes the teacher's ability to increase learning motivation, solve problems, explore good relationships, use specific teaching techniques (Putra, 2012). Teaching English to Young Learners (TEYL) is proliferating in various places, including MI NU Rowolaku, Kec. Kajen, Kab. Pekalongan. English learning still exists even during the COVID-19 pandemic. But unfortunately, this is not supported by the competence of qualified teachers. The teachers in this school are still teaching traditionally. Children in grade 3 have to memorize some existing vocabulary words, even though children at this age have the low concentration power and short memories (Ersoz A, 2007). If the children still memorize vocabulary, they do not know the real object or image from the vocabulary they have memorized. These problems are necessary to be studied so that they can be resolved. Based on the above problems, the authors held a work program called a Home Visit. Home Visit is one of the Real Work Lecture work programs in the form of English language learning assistance for MI children. This learning assistance moved from one student's house to another. Through this home visit, the researcher became closer to the children and knew more deeply about their character to make learning methods easier. With this home visit, children's interest in learning English has increased.

A home visit is one of the real work college work programs $(\mathrm{KKN})$, a place for children to learn English. This program ran three days a week and was voluntary. The Locations moved from one student's house to another. This constantly moving location provided opportunities for children to know their surroundings. Especially for researchers, researchers became closer to the children's parents and knew their conditions at home. During the Covid-19 pandemic, good educators did not only rely on meetings inside and outside the room but also made visits to children's homes as a form of concern for their education. This experience is the first experience teaching English to MI children in the midst of the Covid-19 pandemic. The methods used by previous researchers were still monotonous, such as the methods of lecturing, writing, and memorizing. By using this monotonous method, it was quite difficult for researchers to control the children. They looked busy with their own business and ignored lessons at all. They might feel bored following lessons during the Covid-19 pandemic.

After knowing the condition of the children, the researcher planned a learning strategy, which is drawing, adjusting the characteristics of the child. The benefits of drawing for children, in general, are: 1). Drawing as a storytelling tool (visual language/form), 2) Drawing as a medium for expressing feelings, 3). Drawing as a playing tool, 4). Drawing trains memory, 5). Drawing trains comprehensive thinking (overall), 6) Drawing as a medium for the sublimation of feelings, 7). Drawing trains balance, 8). Drawing develops emotional skills, 9). Drawing trains children's creativity, 10). The age of children is the age with high imagination. So, at this age, let the children express their ideas. One of the means to express it is by drawing. Drawing is visualizing what is on the mind in the form of an image. The connection with learning vocabulary is that children draw the vocabulary they have memorized. By drawing objects in accordance with the memorized vocabulary, it makes it easier for children to remember and know the real objects. Through this drawing, too, trains children to be able to increase their imagination, creativity, cooperation, care and self-confidence. When drawing, the children looked enthusiastic. They draw while imagining objects in their minds and then visualize 
them in pictures. During the drawing, they exchange ideas and share if one of them does not have drawing equipment. Their results differed from one another, but they did not mock each other. After they had finished drawing, the researcher asked the children about the picture and the vocabulary in English. The children's answers are quite good. They are able to know vocabulary as well as objects.

Learning English before and after the Covid-19 pandemic represents a very different process. Face to face in schools in Indonesia has transformed into a learning process entitled Learning From Home. Moreover, the Ministry of Education and Culture has issued Circular Number 15 of 2020, which contains Learning Guidelines from Home related to the intensity of increasing the number of citizens who are indicated to be positive for Covid-19. The emergence of the Covid 19 outbreak around the world and in Indonesia has brought enormous changes in various aspects of life, including education. The government's decision to organize distance learning which is intended to protect students and teachers from the spread of the Covid 19 virus, has various consequences for various parties. Students who learn from home as well as teachers who teach from home, have to struggle with all the challenges and limitations they had never thought of before. School leaders and parents also have to face conditions they never imagined before. These sudden changes are very influential on the teaching and learning process and student achievement, including in English lessons. English has long been a very challenging subject for most students in Indonesia. If in normal or offline learning, students can ask directly to the teacher when they encounter difficulties. Now when learning is required to use an online model, they face unfavorable conditions. Limited learning time, uneven internet network, limited technology and mastery of technology make students no longer able to interrupt too often or ask the teacher when learning is being carried out. Online learning models that are not yet common in Indonesia are also a challenge.

Teachers who have been comfortable with the teaching and learning process in the classroom must work hard to learn how to use various technological devices while learning methods and compiling suitable learning media. This is done with a variety of limitations and increasing task demands. These various conditions really grab the teacher's attention, especially in the first few months of online learning. Over time, teachers have begun to be able to combine their experience and knowledge and creativity in developing various innovative learning models with a variety of interesting tools. Various challenges and conditions related to distance learning, the selection of learning materials and efforts to solve them through interactive media need to be measured for their effects on students' understanding of learning materials and their achievement or achievement scores in learning evaluation. The pandemic is not over and online studies may still be implemented in some areas until conditions improve. Therefore, teachers should continue to improve their abilities to develop material, deliver material, and implement good classroom management so that the quality of learning provided can continue to improve.

In a pandemic situation that requires the implementation of online learning, teachers need to improve their abilities and mastery of technology, especially in making interactive learning media that is attractive so that they are able to produce varied and interesting learning experiences so that children stay focused on learning and are able to improve their understanding of the material provided. On the other hand, students should always focus on taking part in learning so that the results obtained are more optimal, especially in online conditions. In addition, schools should strive to provide facilities and facilities that can support the smooth running of learning activities for all subjects, including English lessons. Regarding the implementation of online classes, Carrillo \& Flores (2020, p.2) explains the use of technology supporting online learning depends on three pedagogical factors. The pedagogical approach, which is the first factor, includes student-centered learning, the role of the teacher as facilitator, and knowledge integration. The second factor is the learning design that includes learning flexibility, learning according to the individual needs of each student, according to context, social, learning process, and use of appropriate tools and technology. Factor to three is facilitation, which includes clear expectations, appropriate questions, understanding and sensitivity to cultural issues, providing timely feedback, constructive and details, and attitude and high commitment from students. Huang et al. $(2020$, p.2) said that also details three main challenges in online learning at the time of pandemic. First, teachers have very limited time preparing and/or adapting to offline 
learning material online. Second, lack or limited opportunity teachers and students interact directly and freely during online learning resulting in disruption of the learning process. Third, using a pedagogical approach effectively requires more effort in motivating and activating students in learning online. Byun \&Slavin $(2020$, p.665) also found that even though school facilities were adequate and the national curriculum facilitates online learning, an imbalance in the education obtained by each student is also due to the influence of family and financial problems that interfere with the learning process.

The first education center is the family environment. Education in the family environment is very strategic to provide education towards intelligence, character or personality, and preparation for life in the community. Parents will be examples for children, and children will usually imitate whatever parents do. So parents must be able to provide good examples and daily habits so that they can be used as examples for their children. Parents should give good examples and habits from childhood because they can affect the mental development of children.

According to Purwanto et al. (2020, p.12), parents also have to pay more to buy internet data in order to facilitate learning activities with their children and communicate or make reports to their teachers. Parents should pay attention to their children's education because the role of parents is significant in the educational process for them. Parents can provide the material needs of their children satisfactorily, but their educational needs are never met. Children are not prepared to become mature humans like the goals that education is trying to achieve. Children develop without any patterns to be aimed at but develop on their own. Children are allowed to grow without the demands of definite norms. There is no certainty in children how they should act or behave because their parents have never been told and guided by them. This kind of situation is called miss educated. Sometimes, the parents are not aware of this kind of thing, so it is not on purpose. Parents do this maybe because they do not know how to educate their children. Alternatively, maybe they know, but they are just too busy. Therefore, to become parents, certain conditions are required so that their children develop well. If a family is blessed with a child, then it is on the parents' shoulders to make efforts to make their children develop properly. So children are not just accepted, given food and clothing, but they should make efforts so that children are able to develop properly. Parents must be able to divide their attention to all objects in the household because it is in the family that the parent-child interaction occurs.

The love given by parents at the beginning of a child's life really helps the child's development and even becomes the basis for laying down his personality. The importance of the role of parents in children's education is not trivial because education is the main asset that every living individual must have in order to survive the times. As of now, parents are increasingly aware of the importance of providing the best education to their children from an early age. Parental involvement in children's education is proven to have many positive impacts on children. Many achieve success after they reach adulthood and dive into the real social world. Of course, the active role of parents needs to be supported by good communication between parents and the school. Like parents who are involved in elementary school (SD) will reap positive effects that will last a child's lifetime. So it is not only the role of teachers and the environment that is important, but parents' role also plays a very important role in children's learning achievement.

Teachers have limitations in explaining learning material related because they lack knowledge and skills regarding learning methods that are carried out. In the previous conventional class, teachers had creativity, flexibility, and diversity in the use of teaching methods that were adjusted to the material, task characteristics, learner characteristics, learning situations and environments, and so on. However, teachers experience limited ability to explain because learning is done online. This also provides challenges to teachers and students in carrying out learning activities. Activities are limited to sharing learning materials, videos, assignments, voice messages, and related information that have limited interaction patterns, from teacher to student and student to teacher. Suputra (2020, p.110) explains that teachers and students are also constrained by learning time, making exposure, explanation, reinforcement, enrichment of learning materials, and clarification of materials difficult. For example, 
some students who do not understand a material during the specified learning period must ask the teacher directly through the teacher's personal WA. Teachers also have limited time and methods or techniques in giving explanations to students satisfactorily because it is quite difficult to give them online. The same thing happened to students. Giving feedback, reinforcements, rewards, and sanctions to students is also very limited. Teachers usually provide corrections to student assignments or projects that are collected, provide verbal reinforcement and rewards such as the words "good, smart, uplifting," and/or provide similar symbols or emoticons to motivate students to learn and participate. However, giving sanctions to students who do not, have not, or are late in submitting assignments cannot be automatically given. The teacher can only remind them continuously every week so that they immediately collect the assignments.

At the basic education level, Rusmiati et al., (2020, p.90) examined the perceptions of 67 elementary school teachers towards online learning in Jakarta, West Java, East Java, Central Java, West Kalimantan. The main finding of this study is that the role of technology readiness in online learning during a pandemic will determine learning success. This technological readiness is also supported by a humanist curriculum, stakeholders' support and participation, including government, schools, teachers, parents of students, and the community. In addition to research, various efforts to help the community solve online learning problems have been carried out during this pandemic. One of them is by Febriyanti et al. (2020, p.17)states who do community service for junior high school English teachers in the Depok area, Indonesia, regarding various online learning platforms in learning English. This activity aims to improve the online learning process during a pandemic, especially with Zoom and Google Meet. This activity can increase teacher literacy towards the two online learning platforms in an effort to maximize the benefits obtained in online learning.

\section{Conclusion}

From the explanation above, it can be concluded that since the outbreak of the Covid-19 pandemic, all learning processes in various parts of the world have changed from face-to-face to online mode. The application of this online mode always provides challenges and also convenience to all parties involved in it. Apart from all that, the role of parents is very necessary in this online learning, where parents must prepare facilities for their children's online learning.

\section{References}

Byun, S., \& Slavin, R. E. (2020). Educational Responses to the COVID-19 Outbreak in South Korea. SSRN Electronic Journal.

Carrillo, C., \& Flores, M. A. (2020). COVID-19 and teacher education: a literature review of online teaching and learning practices. European Journal of Teacher Education.

Crystal, D. (2000).The Cambridge Encyclopedia of Language 3rd (Third) edition. Cambridge University Press.

Ersoz, Aydan, Six Games for the EFL/ESL Classroom, The Internet TESL Journal, Vol, No.6, June 2007

Febriyanti, R. H., \& Sundari, H. (2020). Application Of Use In Online English Based Teaching, Rangkiang: Jurnal Pengabdian Pada Masyarakat UP3M STKIP PGRI Sumatera Barat 17-27.

Harmer, J. (2007).The Practice of English language teaching (4th Ed.). Essex: Pearson Longman.

Huang, R., Tlili, A., Chang, T. W., Zhang, X., Nascimbeni, F., \& Burgos, D. (2020). Disrupted classes, undisrupted learning during COVID-19 outbreak in China: application of open educational practices and resources.

Pinter, A. (2006). Teaching young language learners. China: Oxford University Press.

Puspitasari, D., Rahayu, W. W., Rohmatunnazilah, \& Suwarno. (2020). Exploring the Feelings of International Students: When We Learn Virtually during the COVID-19 Pandemic. Journal of International Students, 10(S3), 142-160. https://doi.org/10.32674/jis.v10iS3.3204

Putra (2012). Model Siklus Belajar (Learning Cycle). www.psb-psma.org

Purwanto, A., Pramono, R., Asbari, M., Hyun, C. C., Wijayanti, L. M., Putri, R. S., \& Santoso, P. B. (2020). Studi Eksploratif Dampak Pandemi COVID-19 Terhadap Proses Pembelajaran 
Online di Sekolah Dasar. EduPsyCouns: Journal of Education, Psychology and Counseling, p.12.

Rusmiati\&Rahmasari (2020).E-Learning Pembelajaran Jarak Jauh. Bandung: YramaWidya.

Richard, J.C.and Rodgers, T. S.(1986). Approach and Methods in Language Teaching.Cambridge, UK: Cambridge University Press.

Sartika, R. (2017). Implementing word wall strategy in teaching writing descriptive text for junior high school students. Journal of English and Education, 5(2), 179-186.

Suputra (2020). Kelas Daring Bahasa Inggris di Masa Pandemi: Sebuah Tantangan Pembelajaran(Paper Presentation). Seminar Nasional Riset Inovatif. ISBN 978-623-7482-543. 